Al-Bayyinah: Journal of Islamic Law-ISSN: 1979-7486 (p);

2580-5088 (e) Volume VI Number 1, pp. 87-110

\title{
STUDI KRITIS LEGISLASI DALAM PERUNDANG-UNDANGAN PERBANKAN SYARIAH
}

\author{
Abul Khair \\ (Pegawai STAIN Watampone, Sulawesi Selatan, Indonesia, \\ email: abulkhair_huzaifah@yahoo.com)
}

\section{Abstract}

The presence of sharia banking in Indonesia is just beginning to develop, following the issuance of Law no. 21 of 2008 on sharia banking, although it has been discourse long before the issuance of the Act, which is more than half a century ago. The delay is due to two things. The first is due to political issues. The labeling of "sharia" in the name of banking institutions in the government's perspective, especially in the New Order regime, is seen as part of the concept of an Islamic state. Another obstacle is the issue of legal umbrella that does not yet exist, because the existing law at that time, namely Law no. 14 of 1967 concerning the Principle of Banking, requires the banking to run with the system of interest, while the interest system is seen as a system that is not Islamic. Herein lies the efforts of various Islamic circles to sharia banking legal umbrella can be realized. Periodically, various renewals are made in the concept of national banking. Religious institutions such as MUI, especially post-legitimacy and full authority to issue fatwa in the field of Islamic economics, succeeded in realizing the expectations of society until finally born a special law on sharia banking. But until now, the implementation of Islamic banking system still leaves a variety of problems and still need to be criticized.

Kata Kunci: Legislasi, Perbankan Syariah. 


\section{I \\ PENDAHULUAN}

Salah satu dimensi yang melekat pada agama ${ }^{1}$ adalah dimensi sosial, dalam arti perilaku manusia pada semua tahap dan aspeknya menjadi cakupan agama. Pemahaman tersebut dapat dipetik dari definisi agama itu sendiri. Agama -paling tidak- didefinisikan sebagai seperangkat kepercayaan dan aturan yang pasti untuk membimbing manusia dalam tindakannya, baik terhadap Tuhan (habl min Alläh) atau antar manusia (habl min al-nās). ${ }^{2}$ Dalam konteks hubungan antar manusia, salah satu aspek yang diatur agama adalah masalah ekonomi.

Terma ekonomi pada umumnya didefinisikan sebagai kajian tentang perilaku manusia, dalam hubungannya dengan pemanfaatan sumber-sumber produktif yang langka untuk memproduksi barang dan jasa, serta mendistribusikannya untuk dikonsumsi sebagai pemenuhan berbagai kebutuhan hidup. ${ }^{3}$ Jika kemudian ekonomi menjadi salah satu aspek yang dicakup dalam pembicaraan agama (Islam), maka tentu menjadi sangat jelas bahwa agama pasti telah memberi tatanan menyangkut kehidupan ekonomi manusia. Dalam al-Qur'an surat al-

${ }^{1}$ Setiap agama -paling tidak- terdiri atas lima dimensi, yaitu: ritual, mistikal, ideologikal, intelektual, dan sosial. Dimensi ritual berkenaan dengan upacara keagamaan, dimensi mistikal menunjukkan pengalaman keagamaan, termasuk juga tawakkal dan ketaqwaan. Dimensi ideologikal mengacu pada perspektif tentang eksistensi manusia sebagai khalifah. Dimensi intelektual menunjukkan tingkat pemahaman terhadap doktrindoktrin agama. Dimensi sosial adalah manifestasi ajaran agama dalam kehidupan bermasyarakat. Lihat dalam, Jalaluddin Rakhmat, Islam alternatif: Ceramah-Ceramah di Kampus (Bandung: Mizan, 2004), h. 37-38. Lihat juga, C.Y. Glock dan R. Stark, Religion and Society in Tension (Chicago: Rand Mc Nally \& Co., 1965), h. 20-21.

${ }^{2}$ Lihat misalya, Dr. H. Ali Anwar Yusuf, M.Si., Islam dan Sains Modern: Sentuhan Islam terhadap Berbagai Disiplin Ilmu (Bandung: Pustaka Setia, 2006), h. 143.

${ }^{3}$ Endang Saefuddin Anshari, Kuliah al-Islam; Pendidikan Agama Islam di Perguruan Tinggi (Jakarta: Raja Grafindo Persada, 1992), h. 154. 
Mutaffifin ayat 1-3 ${ }^{4}$ misalnya, menunjukkan bahwa perilaku curang dalam aktifitas perekonomian menjadi suatu perbuatan terlarang. Alhasil, aktifitas ekonomi dalam Islam sesungguhnya merupakan salah satu manifestasi tanggung jawab manusia sebagai khalifah fí al-ard.

Secara ringkas dapat dikatakan bahwa, tujuan ekonomi Islam adalah makmur dan sejahtera, adil dan merata, tentram (stabil) dan maju, serasi dan damai, merdeka, kelestarian alam, dan mandiri. Muara akhir dan tujuan ideal ekonomi Islam adalah melepaskan tali belenggu kemiskinan yang selama ini melilit mayoritas umat Islam, agar porsi mereka tidak hanya dijadikan sebagai objek pasaran dan konsumen belaka. Dengan kata lain, tujuan ekonomi Islam adalah menciptakan kehidupan manusia yang aman dan sejahtera, terpenuhinya segala kebutuhan baik lahir maupun batin, demi mencapai kebaikan dan kebahagiaan di dunia dan kebaikan di akhirat. ${ }^{5}$

Hal yang patut diakui dewasa ini adalah ekonomi Islam dalam tiga dasawarsa telah mengalami kemajuan yang sangat pesat. Indikator kemajuan yang paling nampak adalah pendirian bank-bank Islam $^{6}$ di belahan dunia, termasuk di

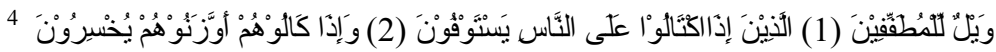
(3)

Terjemahnya:"Celakalah bagi orang-orang yang curang (dalam menakar dan menimbang). (Yaitu) orang-orang yang apabila menerima takaran dari orang lain mereka minta dicukupkan, dan apabila mereka menakar atau menimbang (untuk orang lain), mereka mengurangi......" Departemen Agama RI., Al-Qur'an dan Terjemahnya (Jakarta: Yayasan Penterjemah al-Qur'an, 1983), h. 587.

231.

${ }^{5}$ Dr. H. Ali Anwar Yusuf, M.Si., Islam dan Sains Modern. op.cit., h.

${ }^{6}$ Istilah lain yang digunakan untuk sebutan Bank Islam adalah Bank Syariah. Lihat, Warkum Sumitro, SH., MH., Asas-Asas Perbankan Islam dan Lembaga-Lembaga Terkait; Bamui, Takaful dan Pasar Modal Syariah di Indonesia (Jakarta: Raja Grafindo Persada, 2004), h. 5. Meski dua istilah tersebut dianggap memiliki konotasi yang sama, tetapi M. Cholil Nafis menyatakan bahwa penggunaan term "Syariah" -khususnya dalam konteks pembicaraan ekonomi Islam- adalah khas Indonesia. Di negara lain, kata "Islam" yang digunakan. Karena itu, di Indonesia digunakan istilahistilah seperti "Bank Syariah", bukan "Bank Islam". Lihat, M. Cholil Nafis, Teori Hukum Ekonomi Syariah (Jakarta: UI-Press, 2011), h. iii. Pandangan 
Indonesia. ${ }^{7}$ Pada saat yang sama, bertumbuhkembangnya bankbank yang berbasis syariah di beberapa negara Islam menjadi motivasi bagi forum-forum ulama di Indonesia untuk mendirikan bank syariah. Dalam kurun waktu yang relatif singkat, berdirilah bank-bank syariah yang beriringan dengan upaya legislasi undang-undang perbankan, hingga akhirnya terlahir UU No. 21 Tahun 2008 tentang Perbankan Syariah.

Booming-nya usaha perbankan yang berbasis syariah di Indonesia, juga sesungguhnya merupakan bentuk koreksi atas bank konvensional yang beroperasi dengan sistem bunga yang dianggap oleh sebahagian ulama sebagai riba. ${ }^{8}$ Terlebih masyarakat Indonesia yang memang mayoritas menganut agama Islam, tentu saja berkeinginan untuk menjalankan roda ekonominya pada prinsip-prinsip yang Islami. Karena itu, institusionalisasi perbankan syariah yang diiringi dengan penguatan kelembagaan melalui perumusan undang-undang perbankan syariah, diharapkan mampu memberi jaminan kepastian hukum bagi stakeholders dan keyakinan kepada masyarakat dalam menggunakan produk dan jasa bank syariah.

Kehadiran undang-undang perbankan syariah sesungguhnya merupakan sebuah 'kemenangan' secara politis dan normatif bagi kalangan Islam di Indonesia. Tetapi, regulasi tersebut masih membutuhkan sentuhan penyempurnaan agar setiap materi hukumnya tidak memunculkan pemahaman yang kontra-produktif, seperti halnya pasal tentang penyelesaian sengketa. Jika dicermati pasal 55 UU No. 21 Tahun 2008, di

yang sama dengan M. Cholil Nafis juga dikemukakan oleh Atang Abdul Hakim dalam, Dr. H. Atang Abdul Hakim, MA., Fiqih Perbankan Syariah; Transformasi Fiqih Muamalah ke Dalam Peraturan Perundang-Undangan (Bandung: Refika Aditama, 2011), h. 40.

${ }^{7}$ Babak baru pengenalan terhadap ekonomi Islam sebagai bagian dari ilmu-ilmu keislaman pada dasawarsa 1970-an dan 1980-an dimulai dari kajian-kajian ilmiah tentang ekonomi dan keuangan Islam di Timur Tengah serta negara-negara muslim lainnya. Buah dari kajian-kajian itu adalah didirikannya Islamic Development Bank di Jeddah pada tahun 1975 yang kemudian diikuti oleh pendirian bank-bank Islam lainnya. Prof. Dr. H. Imron Abdullah, M.Ag., "Islam Ditinjau dari Aspek Ekonomi", Kata Pengantar dalam Abdul Aziz, M.Ag., dan Mariyah Ulfah, S.EI., Kapita Selekta Ekonomi Islam Kontemporer (Bandung: Alfabeta, 2010), h. vi.

${ }^{8}$ Lihat, Drs. H. Abdullah Jayadi, SH., MH., Beberapa Aspek Penting tentang Perbankan Syariah (Cet. I; Yogyakarta: Mitra Pustaka, 2011), h. 1. 
satu sisi dikatakan bahwa penyelesaian sengketa perbankan syariah diselesaikan di pengadilan agama, tetapi pada sisi lain ada semacam choice yang justru membuat kompetensi absolut pengadilan agama menjadi terpecah. Sengketa perbankan syariah nampaknya juga memungkinkan diselesaikan melalui jalur lain seperti Badan Arbitrase Syariah Nasional (Basyarnas). ${ }^{9}$ Hal inilah yang hemat penulis menarik untuk dikritisi agar formulasi hukum perbankan syariah benar-benar utuh tanpa bayang-bayang kontroversi di dalamnya.

Dengan berangkat dari alas pikir di atas, tulisan ini perlu diantar dengan sebuah pertanyaan mendasar yang menjadi pokok masalah, yakni: Bagaimana wujud legislasi dalam perundang-undangan perbankan syariah? Tulisan ini sekaligus menjadi sebuah refleksi atas problematika yang ada dalam regulasi perbankan syariah

${ }^{9}$ Eksistensi, tugas dan wewenang Basyarnas didasarkan pada UU No. 30 Tahun 1999, namun pendiriannya dengan SK Dewan Pimpinan MUI No. Kep-09/MUI/XII/2003 tanggal 30 Syawal 1424 H (24 Dsember 2003) tentang Badan Arbitrase Syariah Nasional. Lihat, Drs. H. Abdullah Jayadi, SH., MH., ibid., h. 59. 


\section{II \\ PEMBAHASAN}

\section{A. Latar Belakang dan Sejarah Perbankan Syariah di Indonesia}

Perbankan $^{10}$ dikenal sebagai lembaga yang melaksanakan tiga fungsi utama, yaitu menerima simpanan uang, meminjamkan uang, dan jasa pengiriman/pemindahan uang. Sayangnya, dalam sejarah perekonomian kaum muslimin tidak ditemukan adanya lembaga keuangan yang bernama "bank". Akan tetapi ketiga fungsi utama dari bank telah dikenal sejak zaman Rasulullah saw. Fungsi tersebut adalah menerima titipan harta, meminjamkan uang untuk keperluan konsumsi dan bisnis serta melakukan pengiriman uang. Meskipun demikian, ketiga fungsi tersebut masih dijalankan secara parsial dan individual, bukan dalam bentuk yang lebih integral dan melembaga. ${ }^{11}$

Pada fase perkembangan berikutnya, lembaga yang mengatur masalah finansial dengan label bait al-māl bermetamorfosa menjadi jihbiz. ${ }^{12}$ Pada tahun 1963, muncul

${ }^{10}$ Kata perbankan atau bank telah didefinisikan oleh para ahli dengan pengertian yang cukup beragam. Kendati demikian, definisi-definisi dimaksud sebenarnya memiliki substansi yang sama. Sisi perbedaan yang ada hanya pada tugas atau bidang usahanya saja. Ada yang mendefinisikan bank sebagai suatu badan yang tugas utamanya menghimpun uang pihak ketiga. Yang lain mendefinisikan bank sebagai suatu badan yang tugas utamanya sebagai perantara untuk menyalurkan penawaran dan permintaan kredit pada waktu yang ditentukan. Lihat, Drs. H. Abdullah Jayadi, SH., MH., ibid., h. 2.

${ }^{11}$ Abdul Aziz, M.Ag., dan Mariyah Ulfah, S.EI., Kapita Selekta. op.cit., h. 166. Praktik operasionalisasi kegiatan perbankan pada masa Rasulullah diperankan dalam institusi yang dikenal dengan istilah bait almāl. Kegiatan bait al-māl dipusatkan di masjid karena belum ada bangunan khusus untuk itu. Dengan demikian, masjid bukan hanya berfungsi sebagai tempat iabadah, tetapi juga menjadi wadah untuk berbagai urusan lain seperti masalah ekonomi, hukum, dan lain-lain.

${ }^{12}$ Jihbiz berasal dari bahasa Persia yang berarti Penagih Pajak. Istilah ini mulai dikenal pada masa pemerintahan Muawiyah, yang saat itu fungsinya sebagai penagih dan penghitung pajak atas barang dan tanah, kemudian berkembang menjadi lembaga penukaran uang. Bahkan lebih dari itu, jihbiz juga menerima titipan dana, meminjamkan uang, dan jasa pengiriman uang. Pada zaman Bani Abbasiyah, tiga fungsi utama bank telah 
praktek perbankan Islam komersial di Mesir yang diyakini sebagai embrio dari bank syariah modern, yang kemudian dikenal dengan nama "Mit Ghamr Bank", kendati pada nama bank tersebut tidak menggunakan embel-embel Islam atau syariah. Sejak tahun 1963 hingga tahun 1967, ada sekitar 9 bank yang berdiri di Mesir dengan konsep yang sama, yakni usaha simpanan berbasis profit and loss sharing.

Pada tahun 1971, di Mesir juga didirikan "Naseer Social Bank" yang dideklarasikan sebagai bank komersial bebas bunga. Tiga tahun kemudian, yakni 1974 berdiri pula "Islamic Development Bank (IDB) ”. Secara eksplisit, bank-bank tersebut menyatakan diri sebagai bank yang berdasar pada syariah Islam. Pada tahun 1975, di kawasan Timur Tengah berdiri pula Dubai Islamic Bank, selanjutnya Faisal Islamic Bank of Sudan dan Faisal Islamic Bank of Egyt pada tahun 1977, serta Bahrain Islamic Bank pada tahun 1979. Untuk kawasan Asia Pasifik, tahun 1973 berdiri Philipine Amanah Bank, dan di Malaysia didirikan Muslim Pilgrims Saving Corporation, semacam "Tabungan Haji" untuk membantu mereka yang ingin menabung untuk menunaikan ibadah haji. ${ }^{14}$

Di Indonesia, pendirian bank syariah berhubungan dengan sistem sosial dan entitas kehidupan masyarakat seperti ekonomi, politik, budaya, dan keyakinan keagamaan. ${ }^{15}$ Sebelum

dilakukan secara integral pada satu lembaga. Abdul Aziz, M.Ag., dan Mariyah Ulfah, S.EI., ibid, h. 166-167.

${ }^{13}$ Abdul Aziz, M.Ag., dan Mariyah Ulfah, S.EI., ibid,, h. 167. Informasi lain mengatakan bahwa sebenarnya rintisan awal pendirian Bank Islam dilakukan oleh Pakistan dan Malaysia pada tahun 1940-an, baru disusul oleh Mesir dengan mendirikan "Islamic Rural Bank" di Desa Mit Ghamr dengan nama "Mit Ghamr Bank", yang dibina oleh Ahmad Najjar. Lihat dalam, Dr. H. Atang Abdul Hakim, MA., Fiqih Perbankan Syariah. op.cit, h. 43.

Profit and loss sharing adalah pembagian antara untung dan rugi dari pendapatan yang diterima atas hasil usaha yang telah dilakukan. Atau secara singkat dimaknai sebagai sistem bagi hasil. Lihat, http://tenggarp.blogspot.com/2012/06/pengertian-profit-sharing-danrevenue.html. Diunduh tanggal 5 Oktober 2014.

${ }^{14}$ Abdul Aziz, M.Ag., dan Mariyah Ulfah, S.EI., Kapita Selekta. op.cit., h. 168.

${ }^{15}$ Dr. H. Atang Abdul Hakim, MA., Fiqih Perbankan Syariah. op.cit., h. 39 . 
muncul gagasan tentang perlunya didirikan bank Islam di Indonesia, para pakar/cendekiawan muslim baik yang ada di organisasi keagamaan maupun kalangan perbankan dan perorangan telah melakukan pengkajian tentang bungan bank dan riba. KH. Mas Mansur, ketua pengurus Muhammadiyah pada tahun 1937 telah mempunyai keinginan untuk berdirinya bank Islam. Keinginan tersebut gagal karena ia dianggap SARA pada saat itu dan dikahawatirkan akan mengganggu stabilitas nasional. Majelis Tarjih Muhammadiyah pada Muktamar di Sidoarjo tahun 1968 memutuskan bahwa bunga bank hukumnya termasuk syubhat. Karena itu menurut mereka, untuk menjaga prinsip ihtiyāt perlu ada rambu-rambu untuk menentukan besar kecilnya bunga atau keuntungannya siapa yang peroleh dan untuk siapa keuntungan itu dimanfaatkan. Sementara itu, Bahs al-Masāil NU memfatwakan bahwa bunga bank itu halal, karena bunga bank itu pada hakikatnya merupakan pemanfaatan uang. ${ }^{16}$

Terlepas dari pendapat para pakar yang pro-kontra terhadap hukum bunga bank tersebut, yang pasti kenyataan menunjukkan bahwa umat Islam pada umumnya merasa ragu dan bersikap mendua. Di satu pihak sesuai dengan tuntutan perkembangan kebutuhan ekonomi, masyarakat harus berhubungan dengan bank. Di pihak lain hatinya masih sangat khawatir akan ribanya bunga bank, yang dilarang oleh ajaran agama. $^{17}$

Gagasan pendirian bank syariah telah muncul sejak pertengahan dekade 1970-an. Selanjutnya, gagasan tersebut dibicarakan pada seminar nasional tentang "Hubungan Indonesia-Timur Tegah" (1974) dan seminar internasional yang diselenggarakan oleh Lembaga Studi Ilmu-ilmu Kemasyarakatan (LSIK) dan Yayasan Bhinneka Tunggal Ika (1976). Akan tetapi, ide itu belum bisa terwujud karena beberapa persoalan, seperti masalah payung hukum, ${ }^{18}$ politik $^{19}$

${ }^{16}$ Lihat, Warkum Sumitro, SH., MH., Asas-Asas Perbankan Islam dan Lembaga-Lembaga Terkait; . op.cit., h. 81-82.

${ }^{17}$ Ibid., h. 83.

${ }^{18}$ Ide pendirian bank syariah terkendala dengan perkara hukum menyangkut sistem operasionalisasi yang jika dipaksakan berjalan, maka hal itu akan berbenturan dengan undang-undang yang berlaku saat itu, yakni UU 
dan juga permodalan. Karena itulah, formalisasi syariat Islam dalam bentuk perundang-undangan adalah suatu kemestian. ${ }^{20}$ Harapan pendirian bank syariah mulai terkuak setelah pemerintah mengeluarkan kebijakan deregulasi yang dikenal dengan kebijakan 1 Juni $1983 .^{21}$ Kebijakan ini memberikan

No. 14 Tahun 1967 tentang Pokok Perbankan. Dalam undang-undang dikatakan : "Kredit" adalah penyediaan uang atau tagihan-tagihan yang dapat disamakan dengan itu berdasarkan persetujuan pinjam-meminjam antara bank dengan lain pihak dalam hal mana pihak peminjam berkewajiban melunasi hutangnya setelah jangka waktu tertentu dengan jumlah bunga yang telah ditetapkan". Lihat kembali UU No. 14 Tahun 1967, Pasal 1 poin c, dalam, https://www.dpr.go.id/uu/uu1967/UU_1967_14.pdf, diunduh tanggal 12 Oktober 2014. Artinya, aturan perbankan saat itu menghendaki sistem bunga, sementara konsep yang diusung dalam perbankan syariah adalah sistem bagi hasil (Profit and loss sharing). Perbedaan sistem yang dianut itulah yang membuat bank syariah belum bisa dibentuk.

${ }^{19}$ Dari sisi politik, labelisasi "syariah" yang melekat dalam nama bank cenderung berkonotasi ideologis. Faktor itu nampaknya berpotensi 'mengusik' pemerintah (rezim Orde Baru) yang kala itu secara politis sedang berada dalam ketegangan hubungan politik dengan kalangan Islam. Kalangan Islam bahkan mensinyalir adanya upaya pemerintah dalam beberapa kebijakannya -terutama dalam draf GBHN yang akan dibahas dalam Sidang Umum MPR tahun 1973, yang mengesampingkan agama dalam kehidupan berbangsa- akan menghapus Islam dari bumi Indonesia. Lihat, Dr. H. Atang Abdul Hakim, MA., Fiqih Perbankan Syariah. op.cit., h. 53-54.

${ }^{20}$ Ibid. h. 44-45.

${ }^{21}$ Tanggal 1 Juni 1983, pemerintah melakukan kebijakan deregulasi bidang moneter dan perbankan yang bertujuan untuk meningkatkan efisiensi, pemupukan dana serta kemandirian perbankan. Lihat Anwar Nasution, An Evaluation of the Banking Sectors Reforms in Indonesia 19831993, dan Nopirin, Evaluasi Kebijakan Moneter, Fiskal dan Neraca Pembayaran 1969-1994, dalam, Dr. H. Atang Abdul Hakim, MA., Fiqih Perbankan Syariah . op.cit.,, h. 89. Langkah-langkah deregulasi meliputi : (1) Penghapusan pagu kredit yang semula berlaku untuk masing-masing bank; (2) Mengurangi porsi jenis kredit yang ditunjang oleh likuiditas dari bank sentral; dan (3) memperkenankan perbankan menentukan tingkat suku bunga pinjaman dan pendanaannya sendiri-sendiri. Masyhudi Ali, Restrukturisasi Perbankan dan Dunia Usaha: Pelosok Gelap di Balik Krisis dan Pertikaian Politik (Jakarta: Gramedia, 2002), h. 17. Sebelum kebijakan deregulasi perbankan 1 Juni 1983, Bank Islam tidak bisa beroperasi di Indonesia karena Pemerintah menentukan besarnya tingkat bunga yang harus diterapkan oleh bank. Lihat, Warkum Sumitro, SH., MH., Asas-Asas Perbankan Islam dan Lembaga-Lembaga Terkait; . op.cit., h. 67. 
kebebasan kepada bank pemerintah untuk menentukan suku bunga simpanan dan pinjaman, termasuk suku bunga nol persen. Kebijakan ini memungkinkan adanya bank tanpa bunga dengan sistem bagi hasil sesuai dengan kesepakatan. ${ }^{22}$ Namun, sebelum Pakto $88^{23}$ dan sesudah deregulasi 1 Juni 1983, belum ada umat Islam yang mendirikan bank dan beroperasi tanpa bunga. ${ }^{24}$ Dan memang hingga Oktober 1988, belum ada izin untuk pembukaan bank baru.

Dalam kurun waktu antara 1988 hingga 1992, barulah bermunculan permohonan izin pendirian bank Islam. ${ }^{25}$ Dan titik awal pendirian perbankan yang mempergunakan prinsip syariah, secara faktual ditandai dengan berdirinya PT. Bank Muamalat Indonesia (BMI) TBK pada tahun 1991, dan memulai kegiatan operasionalnya pada bulan Mei 1992. Pendirian bank dimaksud, diprakarsai oleh Majelis Ulama Indonesia (MUI), Pemerintah Indonesia, serta mendapat dukungan nyata dari eksponen Ikatan Cendekiawan Muslim Indonesia (ICMI) dan beberapa pengusaha muslim. Selain itu, pendirian Bank Muamalat Indonesia juga mendapat dukungan dari warga masyarakat yang

\footnotetext{
${ }^{22}$ Lihat, Dr. H. Atang Abdul Hakim, MA., Fiqih Perbankan Syariah. op.cit., h. 45-46.

${ }^{23}$ Istilah "Pakto 88"merupakan singkatan dari Paket Kebijakan Oktober 1988. Pakto 88 itu merupakan serangkaian kebijakan pemerintah mengenai keuangan, moneter, dan perbankan. Di antara kebijakannya adalah adanya kemudahan untuk mendirikan Bank Umum dan BPR (Bank Perkreditan Rakyat). Lihat, Dr. H. Atang Abdul Hakim, MA., ibid, h. 46.

${ }^{24}$ Lihat, Warkum Sumitro, SH., MH., Asas-Asas Perbankan Islam dan Lembaga-Lembaga Terkait; . op.cit., h. 67.

${ }^{25}$ Permohonan tersebut salah satunya diajukan oleh Ibu Saodah dari Lombok untuk mendirikan BPR Islam al-Azhar. Lalu ada BPRS Berkah Amal Sejahtera, BPRS Dana Mardhatillah, BPRS Amanah Rabaniah yang masing-masing beroperasi di Bandung, dan BPRS Hareukat yang beroperasi di Aceh. Semua BPR ini memperoleh izin usaha dari Bank Indonesia. Lihat, Karnaen A. Prawiraatmajdja dan Henri Tanjung, Bank Syariah; Teori, Praktik, dan Peranannya (Jakarta: Celestial Publishing, 2007), h. 88. BPR tersebut menyusul setelah pendirian Bank Muamalat Indonesia. Dan oleh karena lembaga-lembaga itu dirasakan kurang mencukupi dan belum menjangkau masyarakat bawah, maka didirikanlah lembaga simpan pinjam yang kemudian dikenal dengan istilah "Bait al-Māl wa al-Tamwìl" (BMT) atau "Bait al-Qirặ, menurut masyarakat Aceh. Lihat misalnya, Abdul Aziz, M.Ag., dan Mariyah Ulfah, S.EI., Kapita Selekta. op.cit., h. 170.
} 
dibuktikan dengan komitmen pembelian saham Perseroan senilai Rp. 84 miliar pada saat penandatanganan Akta Pendirian Perseroan, dan mendapat tambahan modal senilai 106 miliar dari masyarakat Jawa Barat dalam acara silaturrahmi peringatan pendirian bank tersebut di Istana Bogor. ${ }^{26}$

Seiring berjalannya waktu, pertumbuhan dan perkembangan bank syariah di Indonesia terus merebak. Suhu politik antara pemerintah dan kalangan Islam yang telah mencair pasca berakhirnya rezim Orde Baru, ${ }^{27}$ ditambah dengan dinamika politik hukum yang terus berputar maju demi melahirkan regulasi perbankan syariah, telah berhasil menghadirkan jawaban terhadap kebutuhan mayoritas masyarakat muslim Indonesia yang akan menjalankan usaha ekonominya dengan institusi perbankan yang berprinsip Islam.

\section{B. Kedudukan Perundang-Undangan Perbankan Syariah dalam Hukum Nasional}

Secara de jure, sistem perbankan syariah mulai berjalan setelah ditetapkannya UU. No. 7 Tahun 1992 tentang Perbankan, yaitu dengan diberlakukannya sistem bagi hasil dalam kegiatan usaha perbankan. Di lain sisi, regulasi perbankan syariah berfungsi sebagai aturan main yang membatasi praktik bisnis dari kegiatan garar dan penipuan yang merugikan banyak pihak. Para regulator pun tertuntut untuk bersikap hati-hati dalam menyusun berbagai peraturan, agar instit usi keuangan seperti perbankan dan pelaku bisnis memiliki acuan yang pasti dalam kegiatan usahanya. ${ }^{28}$

Kehadiran industri perbankan syariah sebagai sistem perbankan yang dapat menjadi salah satu pilihan di samping sistem perbankan konvensional di Indonesia dalam satu dasawarsa ini, telah mendapat kekuatan hukum paripurna

${ }^{26}$ Lihat, Dr. Hj. Evita Isretno, SH., MH., Pembiayaan Mudharabah dalam Sistem Perbankan Syariah (Jakarta: Cintya Press, 2011), h. 1.

${ }^{27}$ Lihat misalnya, M. Zaki Mubarak, Geneologi Islam Radikal di Indonesia; Gerakan, Pemikiran dan Prospek Demokrasi (Jakarta: LP3ES, 2007), h. 100.

h. 87 .

${ }^{28}$ Dr. H. Atang Abdul Hakim, MA., Fiqih Perbankan Syariah. op.cit., 
sebagai hukum nasional dengan pemberlakuan Undang-Undang Nomor 21 Tahun 2008 tentang Perbankan Syariah. ${ }^{29}$

Secara umum dapat dikatakan bahwa kedudukan Undang-Undang dalam hierarki perundang-undangan, menempati urutan ketiga tertinggi setelah UUD 1945 dan TAP MPR. $^{30}$ Dengan demikian, kedudukan Undang-Undang Perbankan Syariah dalam hukum nasional memiliki kekuatan hukum yang lebih kokoh serta semakin mempertegas eksistensi institusi perbankan syariah dalam pentas ekonomi nasional.

Pada tingkat konstitusi, legitimasi perbankan syariah di Indonesia tertuang dalam pasal 29 UUD 1945, yakni bahwa negara berdasar atas Ketuhanan Yang Maha Esa dan negara menjamin kemerdekaan tiap-tiap penduduk untuk memeluk agamanya masing-masing dan untuk beribadat menurut agama dan kepercayaannya itu. Sementara pada tingkat undangundang telah disahkan RUU Perbankan Syariah pada tanggal 17 Juni 2008 dan telah diundangkan dalam Lembaran Negara melalui Undang-Undang Nomor 21 tahun 2008 tentang Perbankan Syariah pada tanggal 16 Juli 2008. ${ }^{31}$

Adapun dasar pijakan keluarnya Undang-Undang Nomor 21 tahun 2008 meliputi beberapa peraturan perundangundangan yang telah ada sebelumnya, yaitu :

1. Pasal 20 dan Pasal 33 UUD Negara Republik Indonesia Tahun 1945;

${ }^{29}$ Dr. Hj. Evita Isretno, SH., MH., Pembiayaan Mudharabah. op.cit., h. 3 .

${ }^{30}$ Dalam UU No. 12 Tahun 2011 tentang Pembentukan Peraturan Perundang-Undangan pasal 7 ayat 1 dan 2 dikatakan: 1) Jenis dan hierarki Peraturan Perundang-undangan terdiri atas: a. Undang-Undang Dasar Negara Republik Indonesia Tahun 1945; b. Ketetapan Majelis Permusyawaratan Rakyat; c. Undang-Undang/Peraturan Pemerintah Pengganti Undang-Undang; d. Peraturan Pemerintah; e. Peraturan Presiden; f. Peraturan Daerah Provinsi; dan g. Peraturan Daerah Kabupaten/Kota. (2) Kekuatan hukum Peraturan Perundang-undangan sesuai dengan hierarki sebagaimana dimaksud pada ayat (1). Lihat kembali UU No. 12 Tahun 2011 misalnya dalam, www.djpp.kemenkumham.go.id, diunduh tanggal 14 Oktober 2014.

${ }^{31}$ Prof. Dr. Abdul Gafur Anshori, SH., MH., Hukum Perbankan Syariah; UUNo. 21 Tahun 2008 (Bandung: PT. Refika Aditama, 2013), h. 2. 
2. UU Nomor 7 Tahun 1992 tentang Perbankan (Lembaran Negara Republik Indonesia Tahun 1992 Nomor 31, Tambahan Lembaran Negara Republik Indonesia Nomor 3472) sebagaimana telah diubah dengan UU Nomor 10 Tahun 1998 (Lembaran Negara Republik Indonesia Tahun 1998 Nomor 182, Tambahan Lembaran Negara Republik Indonesia Nomor 3790);

3. UU Nomor 23 Tahun 1999 tentang Bank Indonesia (Lembaran Negara Republik Indonesia Tahun 1999 Nomor 66, Tambahan Lembaran Negara Republik Indonesia Nomor 3843) sebagaimana telah diubah dengan UU Nomor 3 Tahun 2004 (Lembaran Negara Republik Indonesia Tahun 2004 Nomor 7, Tambahan Lembaran Negara Republik Indonesia Nomor 4357);

4. UU Nomor 24 Tahun 2004 tentang Lembaga Penjamin Simpanan (Lembaran Negara Republik Indonesia Tahun 2004 Nomor 96, Tambahan Lembaran Negara Republik Indonesia Nomor 4420);

5. UU Nomor 40 Tahun 2007 tentang Perseroan Terbatas (Lembaran Negara Republik Indonesia Tahun 2007 Nomor 106, Tambahan Lembaran Negara Republik Indonesia Nomor 4756).

Dengan demikian, maka dalam hal pelaksanaan UU Perbankan Syariah dimaksud hendaknya selalu memperhatikan pada UUD 1945, UU Nomor 10 Tahun 1998 tentang Perubahan atas Undang-Undang Nomor 7 Tahun 1992 tentang Perbankan, Undang-Undang Nomor 3 Tahun 2004 tentang Perubahan atas Undang-Undang Nomor 23 Tahun 1999 tentang Bank Indonesia, Undang-Undang Nomor 24 Tahun 2004 tentang Lembaga Penjamin Simpanan, dan Undang-Undang Nomor 40 Tahun 2007 tentang Perseroan Terbatas. ${ }^{32}$

${ }^{32}$ Ibid., h. 3-4. 


\section{Aspek-Aspek Pembaharuan Hukum ${ }^{33}$ dalam Perundang- Undangan Perbankan Syariah}

Pada bagian yang lalu telah penulis uraikan bahwa saat UU No. 7 Tahun 1992 belum dilakukan perubahan, peluang beroperasinya bank Islam (syariah) di Indonesia belum jelas. Kejelasan itu baru diperoleh pasca lahirnya UU No. 10 Tahun 1998 tentang Perubahan atas UU No. 7 tahun 1992. ${ }^{34}$

Jika diurut kembali dari awal, tampak bahwa regulasi perbankan yang mengatur sistem pengelolaan keuangan dalam institusi perbankan hingga akhirnya terlahir undang-undang perbankan syariah, telah beberapa kali mengalami proses pembaharuan hukum. Dan kebijakan tentang pengembangan perbankan syariah tersebut pertama kali disahkan pada tahun 1992. Selanjutnya, pembaharuan dalam regulasi perbankan secara periodik dapat diuraikan sebagai berikut:

1. Periode Tahun 1992

Tanggal 25 Maret 1992 pemerintah menetapkan UU No. 7 Tahun 1992 tentang Perbankan. Undang-undang ini belum lugas menyebut bank syariah. Ia hanya menjelaskan makna kredit dan penyediaan dana berdasarkan prinsip bagi

\footnotetext{
${ }^{33}$ Jika terma "pembaharuan hukum" dipahami dalam konteks Islam, maknanya bermuara pada terminologi tajdid. Kata tajdid pun berkembang maknanya, sehingga istilah-istilah lain seperti "reinterpretasi, reformasi, purifikasi, modernisasi" seringkali disinonimkan dengan tajdid. Penggunaan istilah-istilah semacam ini nampaknya bermuara pada satu titik yang disebut dengan ijtihàd. Dalam bidang ekonomi syariah, ijtihād sebenarnya merupakan hal baru karena perkembangan ekonomi syariah yang begitu cepat dan masih sedikitnya pendapat ahli fikih tentang masalah ini. Jika otoritas ijtihād ekonomi (perbankan) syariah untuk konteks Indonesia dipertajam wilayahnya, maka kewenangan pembaharuan hukum dalam Perundang-Undangan Perbankan Syariah tertuju kepada institusi yang bernama Dewan Syariah Nasional MUI (DSN-MUI). Kewenangan itu adalah menetapkan fatwa sesuai amanat undang-undang. Pada gilirannya, fatwa tersebut pun mengarah kepada wujud taqnin (legislasi) yang baru. Lihat, KH. Ma'ruf Amin, Pembaruan Hukum Ekonomi Syariah Dalam Pengembangan Produk Keuangan Kontemporer: Transformasi Fikih Muamalah dalam Pengembangan Ekonomi Syari'ah, dalam http://mridwancenter.wordpress.com/2012/09/15/184/, diunduh tanggal 16 Oktober 2014.

${ }^{34}$ Warkum Sumitro, SH., MH., Asas-Asas Perbankan Islam. op.cit., h. 76.
} 
hasil sebagai salah satu jenis usaha yang dilakukan, baik oleh Bank Umum maupun oleh BPR. Bagian penting dalam UU ini dan berkorelasi dengan perbankan syariah adalah termuatnya term "bagi hasil" yang dalam ilmu fikih disebut dengan "almuḍarabah". Dan starting point perbankan berbasis syariah berpijak pada term "pembagian hasil keuntungan". ${ }^{35}$

Sebelum UU ini terbit, sistem yang dianut dalam regulasi perbankan adalah sistem bunga (interest). Pembaharuan sistem perbankan pada periode ini dilakukan dengan memadukan dua sistem yang kemudian dikenal dengan istilah "dual banking system", yakni memadukan sistem bunga dengan sistem bagi hasil. Selanjutnya, duo-sistem ini dijelaskan lebih lanjut dalam PP Nomor 72 Tahun 1992 tentang Bank berdasarkan Prinsip Bagi Hasil, bahwa yang dimaksud dengan bank berdasarkan bagi hasil adalah Bank Umum atau BPR yang melakukan kegiatan usaha semata-mata berdasarkan prinsip bagi hasil. Sedangkan yang dimaksud dengan prinsip bagi hasil adalah prinsip muamalah yang berdasarkan bagi hasil untuk menetapkan imbalan. PP ini kemudian dijabarkan lagi dalam Surat Edaran Bank Indonesia No. 25/4/BPPP tanggal 29 Faebruari 1993, bahwa Bank Umum dan BPR tidak diperkenankan menggunakan dua sistem sekaligus. Keduanya hanya diperbolehkan memilih salah satu antara sistem bungan atau sistem bagi hasil (SE BI No. 25/4/BPPP, pasal 16 butir 1 dan 2). ${ }^{36}$

\section{Periode Tahun 1998}

Pada tahun 1998 pemerintah mengeluarkan UU No. 10 Tahun 1998 tentang Perubahan atas UU No. 7 Tahun 1992 tentang Perbankan. UU ini merupakan penyempurna bagi penyempurna UU sebelumnya yang kurang relevan dengan arah dan perkembangan ekonomi nasional, regional, dan internasional yang cenderung menyatu.

Ada beberapa ragam perubahan yang terdapat dalam UU No. 10 Tahun 1998 seperti landasan hukum dan perubahan term "bank berdasarkan prinsip bagi hasil". Jika landasan

\footnotetext{
${ }^{35}$ Lihat, Dr. H. Atang Abdul Hakim, MA., Fiqih Perbankan Syariah.
} op.cit., h. 90-91.

${ }^{36}$ Ibid. h. 92-93. 
hukum dalam UU No. 7 Tahun 1992 meliputi lima UU, maka dalam UU ini meliputi tiga UU. Sementara term "bank yang berdasarkan prinsip bagi hasil" yang terdapat dalam UU No. 7 Tahun 1992 dan PP No. 72 Tahun 1992, diperbaharui oleh UU No. 10 Tahun 1998 diganti menjadi "bank berdasarkan prinsip syariah". ${ }^{37}$ Pada periode ini, Bank Konvensional dimungkinkan membuka unit usaha syariah. ${ }^{38}$ Dengan demikian, sistem perbankan konvensional yang telah ada sebelumnya menjadi semakin lengkap karena di dalamnya diintrodusir sistem perbankan syariah (sistem bagi hasil).

3. Periode Tahun 2008

Pada tahun 2008, pemerintah mengeluarkan UndangUndang Nomor 21 Tahun 2008 tentang Perbankan Syariah tanggal 16 Juli 2008. Jika dibandingkan dengan dua undangundang sebelumnya (UU No. 7 Tahun 1992 dan UU No. 10 Tahun 1998), UU No. 21 Tahun 2008 lebih spesifik dan memiliki kekhususan tertentu. Di antara kekhususuan itu adalah tentang materi diktum pertimbangan, diktum landasan hukum, dan substansi materi UU (hukum materil). Dalam diktum pertimbangan misalnya, kekhususannya yang menarik adalah dicantumkannya prinsip pengembangan sistem ekonomi yang berdasarkan nilai-nilai Islam (syariah) dengan cara mentransformasikan prinsip-prinsipnya ke dalam pengaturan perbankan syariah. Penekanan dalam diktum ini adalah peralihan sistem bunga (riba) ke sistem bagi hasil (almuḍ̄arabah). Inilah salah satu ciri khas dan kelebihan UU No. 21 Tahun 2008, yang tidak ditemukan dalam regulasi sebelumnya. ${ }^{39}$

Bagian lain dalam pembaharuan hukum pada periode ini tampak dalam proses adaptasi dan harmonisasi fikih muamalah ke dalam UU No. 21 Tahun 2008. Masuknya fikih muamalah ke dalam Undang-Undang Perbankan Syariah ini tidak lepas dari proses pembentukannya. UU ini disetujui untuk disahkan oleh fraksi-fraksi partai politik dan pemerintah pada

\footnotetext{
${ }^{37}$ Ibid. h. 94-95.

${ }^{38}$ Abdul Aziz, M.Ag., dan Mariyah Ulfah, S.EI., Kapita Selekta. op.cit., h. 171.

${ }^{39}$ Lihat, Dr. H. Atang Abdul Hakim, MA., Fiqih Perbankan Syariah. op.cit., h. 105-108.
} 
rapat paripurna DPR RI tanggal 17 Juni 2008 yang dihadiri oleh 328 anggota DPR dari jumlah anggota 549 orang, kecuali Partai Damai Sejahtera (PDS). Proses transformasi melalui adaptasi dan harmonisasi fikih muamalah ke dalam UU diawali dengan pembuatan naskah akademik UU, pembahasan RUU di fraksi, dan pembahasan di paripurna untuk disetujui dan disahkan. ${ }^{40}$

Secara umum, materi fikih muamalah yang termuat dalam UU No. 21 terdapat dalam pasal 1, 19 dan 21. Dalam naskah akademik, materi fikih muamalah belum secara spesifik ditempatkan di pasal dan ayat tertentu, tetapi baru sebatas kerangka konseptual. Naskah akademik menempatkan al-tauhid sebagai pilar utama ekonomi syariah yang melahirkan beberapa prinsip seperti al-khiläfah, al-'adālah, al-nubuwwah, alukhuwwah, dan al-hurriyyah wa al-masūliyyah. Di samping itu, larangan riba, kewajiban zakat, kerjasama, jaminan sosial, dan peran negara dikategorikan oleh naskah akademik sebagai instrumental ekonomi syariah. ${ }^{41}$

Potret pembaharuan hukum dalam UU No. 21 Tahun 2008 dapat dikelompokkan menjadi tiga bagian, yaitu:

a. Asas pertukaran manfaat, asas kerjasama dan asas hak milik dalam UU No. 21 Tahun 2008;

b. Asas pemerataan, 'an tarạ̈̂in, dan 'adam al-garar;

c. Asas al-birr wa al-taqwā.

Terkait dengan UU No. 21 Tahun 2008, asas pertukaran manfaat, asas musyarakah, asas kepemilikan, dan tolong-menolong terlihat dalam pasal UU ini. Fungsi perbankan syariah seperti tertuang dalam Pasal 4 melewati fungsi perbankan nasional. Ia tidak hanya menghimpun dan menyalurkan dana masyarakat seperti halnya bank konvensional, tetapi juga melaksanakan fungsi sosial dalam bentuk bait al-māl dengan menerima zakat, infak, sedekah, hibah, dana sosial lainnya, dan dana dari wakaf uang. ${ }^{42}$

Secara implisit, asas pemerataan -misalnya- termuat dalam aturan mengenai fungsi dan kegiatan usaha Bank Umum Syariah (BUS) atau Unit Usaha Syariah (UUS). Fungsi kedua

\footnotetext{
${ }^{40}$ Ibid., h. 160-181.

${ }^{41}$ Ibid., h. 127.

${ }^{42}$ Ibid., h. 160.
} 
lembaga ini adalah: (1) menghimpun dan menyalurkan dana masyarakat; dan (2) fungsi sosial. Dari fungsi pertama tampak bahwa aturan memberikan kesempatan secara merata kepada seluruh lapisan masyarakat untuk memanfaatkan kegiatan usaha perbankan syariah dengan menyimpan dana mereka di bank, sekaligus dapat mengajukan permohonan untuk mendapatkan kucuran pembiayaan yang disalurkan oleh lembaga tersebut. Fungsi kedua terkait dengan penerimaan dana yang berasal dari zakat, wakaf, infak, sedekah, dan hibah. Aturan pendistribusian dana memungkinkan iklim pemerataan keemilikan dan pemanfaatan harta secara adil., sehingga semua orang bisa menikmatinya. ${ }^{43}$

Selanjutnya, ruh dari asas al-birr wa al-taqwā diindikasikan dalam isi pasal 26 UU No. 21 Tahun 2008. Ia mengatur tentang kewajiban ketundukan kegiatan usaha dan atau produk serta jasa syariah kepada prinsip syariah yang difatwakan oleh MUI dan dituangkan dalam Peraturan Bank Indonesia (PBI). Sebuah materi fatwa manakala ia diadaptasi ke dalam UU (taqnin), berubah menjadi mengikat dan berkekuatan hukum. Karena itu, sesuai amanat pasal 26, prinsip syariah yang berupa fatwa ini adalah sumber pembentukan UU No. 21 Tahun 2008 yang ketika menjadi UU, ia wajib ditaati oleh para pelaku perbankan syariah. $^{44}$

\section{Analisis Kritis Sekitar Konstruksi Hukum Penyelesaian Sengketa Perbankan Syariah}

Secara normatif, telah banyak produk pembaruan hukum dalam Undang-Undang Perbankan yang sebahagian di antaranya telah penulis uraikan. Dari sisi teknis, tentu regulasi yang ada diharapkan mampu menjamin proses interaksi ekonomi moneter dalam institusi perbankan dapat berjalan secara ideal. Praktek pengelolaan perbankan perlu secara nyata menunjukkan nilai syariah, sehingga pilihan masyarakat akan semakin lebih besar untuk ke bank-bank syariah dibanding ke bank-bank konvensional. Apatahlagi secara filosofis, aktifitas perbankan yang dilakukan pada bank-bank syariah tentu dapat bernilai ibadah. Karena itu, hal-hal yang masih mungkin

\footnotetext{
${ }^{43}$ Ibid., h. 169.

${ }^{44}$ Ibid., h. 183-184.
} 
membuat masyarakat kurang yakin perlu diminimalisir (kalau belum bisa dikatakan dihilangkan). Sebagai contoh, prosedur pengambilan kredit pada bank-bank syariah justru oleh sebahagian- masyarakat dinilai lebih 'menyiksa' karena prosesnya yang panjang dan berbelit. Persyaratan yang dibuat bahkan cenderung dinilai tidak syariah lagi karena sangat memberatkan. Hal-hal semacam itu yang masih seringkali dipertanyakan oleh beberapa kalangan masyarakat. Kondisi seperti itu juga menjadi sebuah fakta bahwa semangat yang ada dalam upaya melegislasi sistem perbankan syariah, berbanding terbalik dengan respon masyarakat yang kelihatan masih rendah terhadap eksistensi bank-bank syariah pasca terwujudnya undang-undang perbankan syariah. Atas dasar itu pula kemudian penulis ingin menyatakan bahwa tingkat kepercayaan masyarakat terhadap perbankan syariah sangat penting untuk terus dibangun.

Aktifitas perbankan yang telah didukung oleh regulasi yang memadai, memang bukan tanpa potensi masalah. Dalam konteks ini penulis ingin menggaris bawahi satu hal bahwa ketika terjadi sengketa dalam perbankan syariah, mestinya undang-undang tidak mengatur proses penyelesaiannya dengan memberi pilihan-pilihan penyelesaian sengketa pada institusi yang berbeda. Pasal 55 UU No. 21 Tahun 2008 -misalnya- yang menjelaskan penyelesaian sengketa perbankan syariah, di sana diperoleh keterangan bahwa hal itu menjadi kewenangan Pengadilan Agama. ${ }^{45}$ Tetapi pada saat yang sama, UU No. 30 Tahun 1999 tentang Badan Arbitrase Nasional Indonesia (BANI) juga memberi peluang penyelesaian sengketa perbankan syariah untuk diselesaikan melalui jalur arbitrase ${ }^{46}$

${ }^{45}$ Dalam pasal tersebut juga tergambar adanya perluasan kewenangan bagi Pengadilan Agama yang tadinya hanya berada pada wilayah hukum keluarga, dan kemudian merambah pada wilayah ekonomi syariah. Dengan demikian dipahami pula bahwa perkara ekonomi syariah juga telah menjadi kompetensi absolut Pengadilan Agama.

${ }^{46}$ Istilah "arbitrase" secara sederhana dapat dimaknai sebagai "juru damai". Menurut Abdullah Jayadi, Arbitrase adalah lembaga yang paling umum digunakan untuk menyelesaikan sengketa komersial dalam lingkup baik transaksi bisnis domestik maupun bisnis internasional yang posisinya berada di luar pengadilan yang tergolong dalam lingkungan ADR. Drs. H. Abdullah Jayadi, SH., MH., Beberapa Aspek Penting op.cit., h. 57. Dalam 
dan atau Basyarnas. ${ }^{47}$ Hal semacam itulah yang -sekali lagisebenarnya berpotensi membingungkan masyarakat dan perlu dihindari. Keniscayaan menyelesaikan sengketa perbankan syariah pada institusi yang beragam itu, justru membuat kompetensi absolut Pengadilan Agama menjadi patut dipertanyakan.

Secara umum undang-undang mengatakan bahwa dalam hal eksekusi keputusan yang dikeluarkan oleh badan arbitrase, ada satu prinsip hukum yang secara umum berlaku, yaitu putusan arbitrase bersifat independen, sehingga tidak dapat diintervensi oleh ketua Pengadilan Negeri ketika dilaksanakan eksekusi. Pasal 62 ayat (4) UU Arbitrase No. 30 Tahun 1999 dengan tegas melarang ketua Pengadilan Negeri untuk memeriksa alasan dan pertimbangan dari putusan arbitrase. Dengan demikian, ketua Pengadilan Negeri hanya mempunyai kewenangan untuk meninjau suatu putusan arbitrase secara formal, bukan secara material. Putusan arbitrase bersifat mandiri, final, dan mengikat atau berkekuatan hukum tetap. ${ }^{48}$

Problem yang sebenarnya dimunculkan undang-undang menyangkut hubungan antara kompetensi Peradilan Agama dan Basyarnas, bermula pada penyetaraan Peradilan Umum dengan Peradilan Agama sebagai dua institusi yang sama kedudukannya, berdasarkan penjelasan Pasal 24 UUD 1945 dan UU No. 4 Tahun 2004. Selanjutnya, hubungan Peradilan Umum dengan Arbitrase dalam ketentuan UU No. 30 Tahun 1999 tentang Putusan Badan Arbitrase, memberi konsekuwensi logis untuk dianggap berlaku sama untuk Basyarnas (Pasal 25 ayat $6) .^{49}$

sejarah perbankan Islam di Indonesia dikenal lembaga yang serupa, yakni Badan Arbitrase Muamalat Indonesia (BAMUI), yang resmi berdiri pada tanggal 21 Oktober 1993. Lihat, Warkum Sumitro, SH., MH., Asas-Asas Perbankan Islam. op.cit., h. 165. BAMUI kemudian berubah bentuk menjadi Basyarnas.

${ }^{47}$ Eksistensi, tugas dan wewenang Basyarnas didasarkan pada UU No. 30 Tahun 1999, dan didirikan berdasarkan SK Dewan Pimpinan MUI No. Kep-09/MUI/XII/2003 tanggal 24 Desember 2003. Lihat, Drs. H. Abdullah Jayadi, SH., MH., Beberapa Aspek Penting. op.cit., h. 59.

${ }^{48}$ Ibid., h. 109.

${ }^{49}$ Ibid. h. 79. 
Dalam kaitannya dengan putusan Basyarnas, penjelasannya dapat diperoleh dalam Peraturan Prosedur Basyarnas -misalnya- pasal 25 ayat (1), yakni :

"Putusan Basyarnas yang sudah ditandatangani oleh Arbiter Tunggal atau Arbiter Majelis bersifat final dan mengikat (final and binding) bagi para pihak yang bersengketa, dan wajib ditaati serta dilaksanakan secara sukarela". 50

Bahkan dalam pasal yang sama, Peraturan Prosedur Basyarnas atau putusan Basyarnas justru dikaitkan dengan Pengadilan Negeri ataupun BANI, bukan dengan Pengadilan Agama. Problem yang mencolok di dalam regulasi tersebut adalah komptensi absolut Pengadilan Agama untuk menyelesaikan sengketa ekonomi syariah (Pasal 55 UU No. 21 Tahun 2008) menjadi 'mengambang' jika diukur menurut isi Pasal 25 ayat 6 dalam Peraturan Prosedur Basyarnas, yang boleh jadi hanya merupakan bentuk 'duplikasi' pasal-pasal yang terdapat dalam UU Arbitrase No. 30 Tahun 1999. Pemahaman yang dimunculkan undang-undang tersebut adalah Pengadilan Agama tidak mempunyai kewenangan untuk meninjau suatu putusan Basyarnas.

Dari uraian di atas terlihat jelas potensi yang akan membingungkan masyarakat mengenai penyelesaian sengketa perbankan syariah, terutama menyangkut ketentuan dalam Peraturan Prosedur Basyarnas. Sebab peraturan Basyarnas tersebut bersinggungan dengan eksistensi Peradilan Agama dalam segala kewenangan atau kompetensi absolutnya menyangkut sengketa ekonomi syariah. Hal inilah yang perlu dikritisi dan perlu ditinjau kembali dalam regulasi yang sudah ada. Wajar jika kemudian Abdullah Jayadi melontarkan sentilan seperti yang tertulis dalam bukunya dengan menyatakan "Jangan asal jiplak saja ketentuan UU No. 30 Tahun 1999 tanpa memperhatikan UU lain yang terkait, seperti UU No. 3 Tahun $2006 " .51$

\footnotetext{
${ }^{50}$ Ibid, h. 112.

${ }^{51}$ Ibid., h. 114.
} 


\section{PENUTUP}

\section{A. Kesimpulan}

Setelah menguraikan beberapa aspek yang berkaitan dengan sejarah, kedudukan, aspek-aspek pembaharuan dalam perundang-undangan perbankan syariah, sekaligus hal-hal yang patut dikritisi, maka kesimpulan yang dapat dipetik dalam tulisan ini adalah:

1. Gagasan pendirian bank syariah telah muncul sejak pertengahan dekade 1970-an. Namun, pendirian bank syariah mulai terkuak setelah pemerintah mengeluarkan kebijakan deregulasi yang dikenal dengan kebijakan 1 Juni 1983. Dan titik awal pendirian perbankan yang mempergunakan prinsip syariah ditandai dengan berdirinya PT. Bank Muamalat Indonesia TBK pada tahun 1991. Pendirian BMI diprakarsai oleh Majelis Ulama Indonesia (MUI), Pemerintah Indonesia, serta mendapat dukungan nyata dari eksponen Ikatan Cendekiawan Muslim Indonesia (ICMI) dan beberapa pengusaha muslim. Hal itu dilakukan dengan mengingat kenyataan yang menunjukkan bahwa umat Islam pada umumnya merasa ragu dan bersikap mendua terhadap bungan bank, apakah hukumnya haram karena sama dengan riba, ataukah halal. Padahal, sesuai dengan tuntutan perkembangan kebutuhan ekonomi, masyarakat harus berhubungan dengan bank di satu pihak, sementara di pihak lain, kekhawatiran akan 'haramnya' bunga bank terus menghantui.

2. Kedudukan Undang-Undang Perbankan Syariah dalam hukum nasional memiliki kekuatan hukum yang lebih kokoh serta semakin mempertegas eksistensi institusi perbankan syariah dalam pentas ekonomi nasional. Dengan demikian, ia wajib ditaati oleh para pelaku perbankan syariah.

3. Aspek pembaharuan dalam regulasi perbankan syariah dapat dikatakan mengalami transformasi hukum secara periodik, yakni periode tahun 1992, periode tahun 1998 dan periode tahun 2008. Pada periode 1992, perbankan memperkenalkan konsep perbankan syariah berbasis "bagi hasil" yang dalam ilmu fikih disebut dengan "al-muḍarabah". Dan starting point perbankan berbasis syariah berpijak pada term 
“pembagian hasil keuntungan". Pada periode 1998, perbankan memadukan dua sistem yang kemudian dikenal dengan istilah "dual banking system", yakni memadukan sistem bunga dengan sistem bagi hasil. Pada periode 2008, pemerintah telah mengeluarkan Undang-Undang tentang Perbankan Syariah. Undang-undang ini -antara lain- telah menegaskan peralihan sistem bunga (riba) ke sistem bagi hasil (al-muḍārabah).

4. Penyelesaian sengketa perbankan syariah menurut undangundang bukan hanya dapat diselesaikan di Pengadilan Agama sebagaimana tersurat dalam Pasal 55 UU No. 21 Tahun 2008, tetapi memungkinkan diselesaikan melalui institusi lain seperti Basyarnas (Peraturan Prosedur Basyarnas Pasal 25 ayat 6 atau UU Arbitrase No. 30 Tahun 1999). Meski undang-undang meligitimasi hal tersebut, tetapi konsekwensi lain yang muncul adalah soal kompetensi absolut Pengadilan Agama. Nampaknya UU yang kontraproduktif itu perlu ditinjau ulang.

\section{B. Saran}

Tulisan ini telah menyajikan topik bahasan tentang studi kritis legislasi dalam perundang-undangan perbankan syariah. Penulis meyakini bahwa proses akselerasi pengembangan ekonomi syariah pun tentu senantiasa diharapkan maju pesat di Indonesia.

\section{DAFTAR PUSTAKA}

Rakhmat, Jalaluddin. Islam alternatif: Ceramah-Ceramah di Kampus. Bandung: Mizan, 2004

Yusuf, M.Si., Dr. H. Ali Anwar. Islam dan Sains Modern: Sentuhan Islam terhadap Berbagai Disiplin Ilmu. Bandung: Pustaka Setia, 2006

Anshari, Endang Saefuddin. Kuliah al-Islam; Pendidikan Agama Islam di Perguruan Tinggi. Jakarta: Raja Grafindo Persada, 1992

Departemen Agama RI., Al-Qur'an dan Terjemahnya. Jakarta: Yayasan Penterjemah al-Qur'an, 1983. 
Warkum Sumitro, SH., MH. Asas-Asas Perbankan Islam dan Lembaga-Lembaga Terkait; Bamui, Takaful dan Pasar Modal Syariah di Indonesia. Jakarta: Raja Grafindo Persada, 2004.

Nafis, M. Cholil. Teori Hukum Ekonomi Syariah. Jakarta: UIPress, 2011.

Abdul Hakim, MA., Dr. H. Atang. Fiqih Perbankan Syariah; Transformasi Fiqih Muamalah ke Dalam Peraturan Perundang-Undangan. Bandung: Refika Aditama, 2011.

Jayadi, SH., MH., Drs. H. Abdullah. Beberapa Aspek Penting tentang Perbankan Syariah. Cet. I; Yogyakarta: Mitra Pustaka, 2011.

http://tenggarp.blogspot.com/2012/06/pengertian-profitsharing-dan-revenue.html. Diunduh tanggal 5 Oktober 2014.

https://www.dpr.go.id/uu/uu1967/UU-1967-14.pdf, diunduh tanggal 12 Oktober 2014.

Masyhudi. Restrukturisasi Perbankan dan Dunia Usaha: Pelosok Gelap di Balik Krisis dan Pertikaian Politik. Jakarta: Gramedia, 2002.

A. Prawiraatmajdja, Karnaen dan Henri Tanjung, Bank Syariah; Teori, Praktik, dan Peranannya. Jakarta: Celestial Publishing, 2007.

www.djpp.kemenkumham.go.id, diunduh tanggal 14 Oktober 2014.

Gafur, SH., MH., Prof. Dr. Abdul. Hukum Perbankan Syariah; UU No. 21 Tahun 2008. Bandung: PT. Refika Aditama, 2013.

Amin, KH. Ma'ruf. Pembaruan Hukum Ekonomi Syariah dalam Pengembangan Produk Keuangan Kontemporer: Transformasi Fikih Muamalah dalam Pengembangan Ekonomi Syari'ah, dalam http://mridwancenter.wordpress.com/2012/09/15/184/, diunduh tanggal 16 Oktober 2014. 